\title{
The Impact of Constantinopolitan Liturgy on the Mosaic Pavements in the Christian Basilicas in Thrace during the Second Half of 5th C.
}

\section{Yüzyılın İkinci Yarısında Trakya'daki Hristiyan Bazilikalarında Konstantinopolis Litürjisinin Mozaik Döşemelere Etkisi}

Ivo TOPALILOV*

(Received 06 March 2021, accepted after revision 29 August 2021)

\begin{abstract}
The present article deals with changes that occurred in the arrangement of the mosaic floor decorations of two important basilicas located in the capitals of two provinces in Thrace - the Episcopal basilica at Philippopolis and the basilica at Herakleia, which are both dated to the second half of the $5^{\text {th }} \mathrm{c}$. The study reveals that in these cases the changes were not a purely decorative issue with the introduction of a new trend in mosaic decoration. Instead, these were innovations that reflected the new importance of the areas marked by mosaic decoration, such as the 'entrance' in the atrium or narthex and the side aisles and their middle portions. It seems they were part of the introduction of the Constantinopolitan liturgy that emerged after the reassignment of Thrace to the jurisdiction of the Constantinopolitan church pursuant to canon 28 of the Fourth Ecumenical council at Chalcedon in 451. In order to avoid any misunderstandings, the new sites were marked by specific and clear Christians images. Dating to the second half of the $5^{\text {th }} \mathrm{c}$., the Thracian examples are among the earliest so far attested and reveal the evolution of the Constantinopolitan liturgy before its completion, which is eventually attested in the monuments of the $6^{\text {th }} c$. in the capital and elsewhere.
\end{abstract}

Keywords: Liturgy, Constantinople, Thrace, Fourth Ecumenical council, Christian basilica.

$\ddot{\mathrm{O} z}$

Bu makale, iki eyaletin başkentinde yer alan ve her ikisi de 5. yüzyılın ikinci yarısına tarihlenen Trakya'daki iki önemli bazilikanın, Philippopolis 'teki Piskoposluk Bazilikast ve Heraklea'daki Bazilika'nın, mozaik zemin süslemelerinin düzenlenmesinde meydana gelen değişiklikleri ele almaktadır. Çalışma, bu durumlarda, mozaik süslemede yeni bir akımın ortaya çıkmasıyla birlikte değişikliklerin salt dekoratif bir mesele olmadı̆̆ını ortaya koymaktadır. Bunun yerine, bu özellikler atrium veya narteksteki 'giriş've dış nefler ile bunların orta kısımları gibi mozaik bezeme ile işaretlenen alanların yeni önemini yansıtan yeniliklerdi. Görünüşe göre bunlar, 451'de Kalkedon'daki Dördüncü Ekümenik Konsil'in 28. kanonu uyarınca Trakya'nın Konstantinopolis kilisesinin yargı yetkisine yeniden verilmesinden sonra ortaya çıkan Konstantinopolis liturjisinin tanıtımının bir parçası gibi görünmektedir. Herhangi bir yanlış anlamadan kaçınmak için, yeni kentler belirli ve net Hristiyan sembolleri ile işaretlenmiştir. 5. yüzyılın ikinci yarısına tarihlenen Trakya örnekleri, şimdiye kadar onaylanmış en erken örnekler arasindadır. Bu örnekler Konstantinopolis liturjisinin tamamlanmadan önceki evrim sürecini ortaya koymaktadır ve bu süreç sonunda başkentte ve başka yerlerde 6. yüzyıla ait anıtlarda kanıtlanmıştır.

Anahtar Kelimeler: Liturji, Konstantinopolis, Trakya, Dördüncü Ekümenik konsil, Hristiyan bazilikası.

\footnotetext{
Ivo Topalilov, Institute of Balkan Studies with Center of Thracology "Prof. Alexander Fol" - Bulgarian Academy of Sciences, 13 Moskovska Str., 1000 Sofia, Bulgaria. (D) https://orcid.org/0000-0002-0565-2054. E-mail: ivo.topalilov@balkanstudies.bg; itopalilov@yahoo.com

This paper was written in the framework of the project LABedia: encyclopedia of Late Antique Balkans, $4^{\text {th }}$ century, financed by the National Science Fund, Contract KH-06-H30/6, 13.12.2018.

I would like to thank the anonymous reviewers for their valuable comments that improve the text. I would like to emphasize that when disagree, the decision is entirely mine and therefore the mistakes. My sincere thanks go to Dr. Matthew Schueller for proofreading of text.
} 
It seems that the Episcopal basilica in Philippopolis received a new mosaic pavement decoration very soon after the end of the Huns' invasions of Thrace in the third quarter of the $5^{\text {th }}$ century. The mosaic covered the previously geometric ones in the naos, narthex, and rooms in the southern and northern part of the atrium (Fig. 1). As the new mosaic pavement still awaits full publication ${ }^{1}$, a brief description is needed for the purpose of this study. ${ }^{2}$
Figure 1

General layout of the uncovered mosaic pavement in the Episcopal basilica in Philippopolis (after Tankova 2017: 324 fig. $1)$.

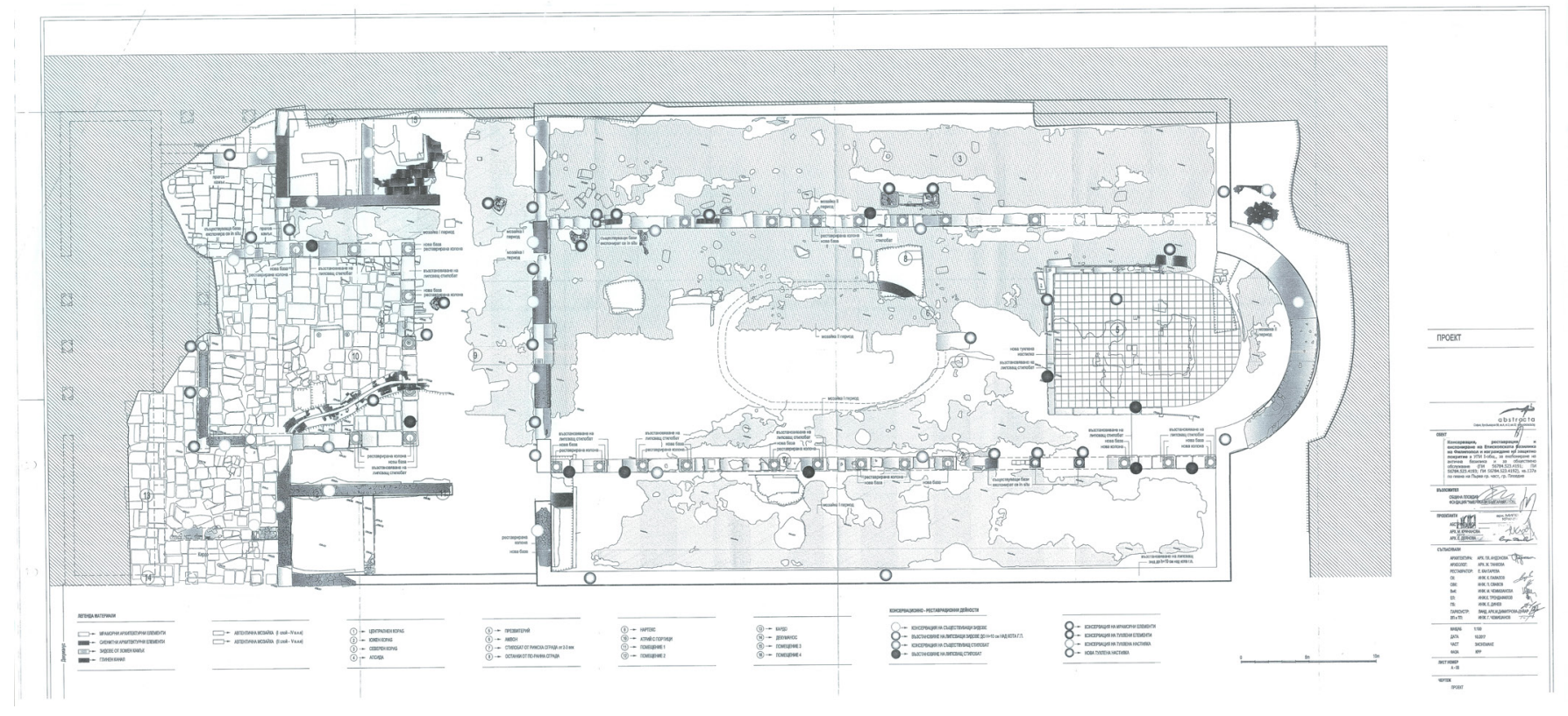

The mosaic floor was carried out in mixed techniques: opus vermiculatum, opus tessellatum, and opus sectile. While the opus sectile was used only once in the altar area, the combination of the other two techniques featured in the decoration that covered the rest of the complex's floors. The new pavement surface was broken up in a sequence of three panels in the side aisles and central nave. Some other smaller panels are located on both sides of the altar area to the north and south and in the apse (Pillinger et al. 2016: 216). The iconography of the first panel in the nave consists of two compositions: a small entirely geometric scene at the center of the ambo and geometric patterns combined with images of birds, a vessel (a krater or kantharos), and a bucket. A certain sequence in the inclusion of these items cannot be established in either the horizontal or vertical row. The birds are presented individually or as a pair, free or caged, with and without plants, etc., within geometrically framed squares (Décor I: pl. 69f). Despite the numerous images (more than 70), only a few species are presented: an eagle, a peacock, a galeeny, a hen, and a duck. The second panel is filled with polychrome orthogonal pattern of circles interlooped tangentially (Décor I: pl. 235a) with a 'diamond' and a stylized rosette. The third panel consists of a polychrome orthogonal pattern of intersecting circles, which form saltires and concave squares with circles (Décor I: pl. 238e - variant). All of the panels are framed by a general border filled with ivy scroll pattern with or without grapes. The first panel has a frame of its own.

The iconography of the mosaic pavements in the side aisles is symmetrical, with

1 The mosaics have been published in Kesjakova 2011: 173-210; Pillinger et al. 2016: 198-220; Popova 2016: 163-166; Kantareva-Decheva 2017: 220-227; 2018: 365-372; Popova 2018: 138-140 and bibliography cited there.

2 An aerial view of the mosaics in the nave and north aisle is available at https://en.wikipedia.org/wiki/ Great_Basilica,_Plovdiv\#/media/File:Basilica_Philippopol_3.png (consulted on March, $6^{\text {th }}, 2021$ ). 
Figure 2

The south aisle of the Episcopal

basilica in Philippopolis with the small square panel in the center (after Pillinger et al. 2016: taf. $154 \mathrm{Abb} .401)$.

Figure 3

The Fons vitae in the south aisle of the Episcopal basilica in Philippopolis (after Pillinger et al. 2016: taf. 158 Abb. 409).

two heavily elongated panels on both sides of a smaller square in the center (Fig. 2 ). The overall motif is the image in the central panel - that of the 'Fountain of Life' (fons vitae) with two peacocks resting on both sides of a fountain in the form of a kantharos (Fig. 3). The picturesque nature of this scene is achieved through polychromy as well as redundantly decorated organic elements. The orientation of both scenes is west-south. As in the first panel in the nave, these panels have another frame of their own.
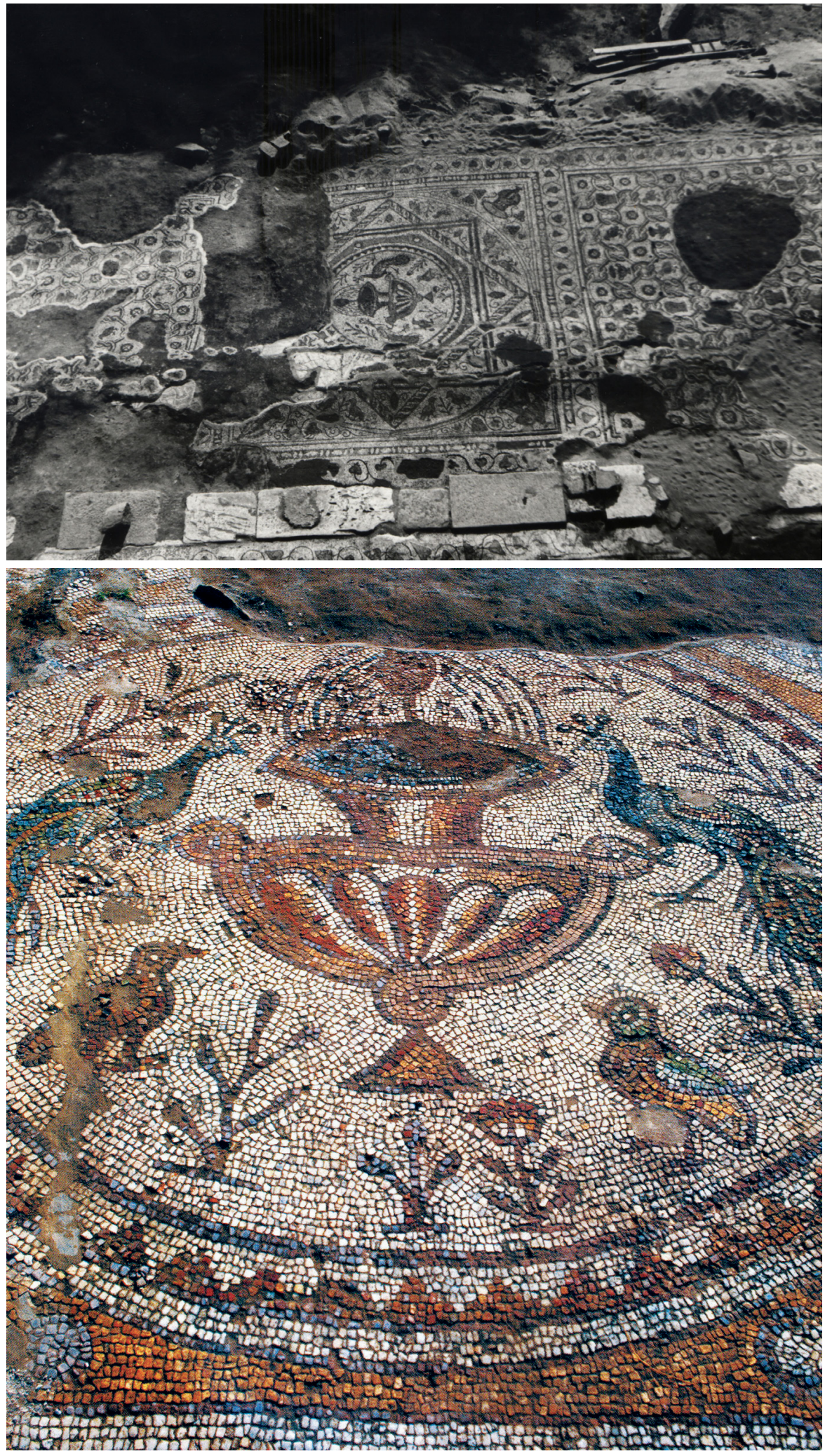
These central panels were without a doubt the focus of the side aisles' mosaic floor decoration. In the other panels in which figural motifs are presented, they are in much smaller scale and more humbly presented as an ordinary element of the whole decoration (Fig. 4). These images consist of a polychrome gridpattern of Heracles' knots (Décor I: pl. 254f) with the space between filled with a kantharos, a wicker basket of fruits (probably pears or apples), birds, and stylized rosettes with four petals.

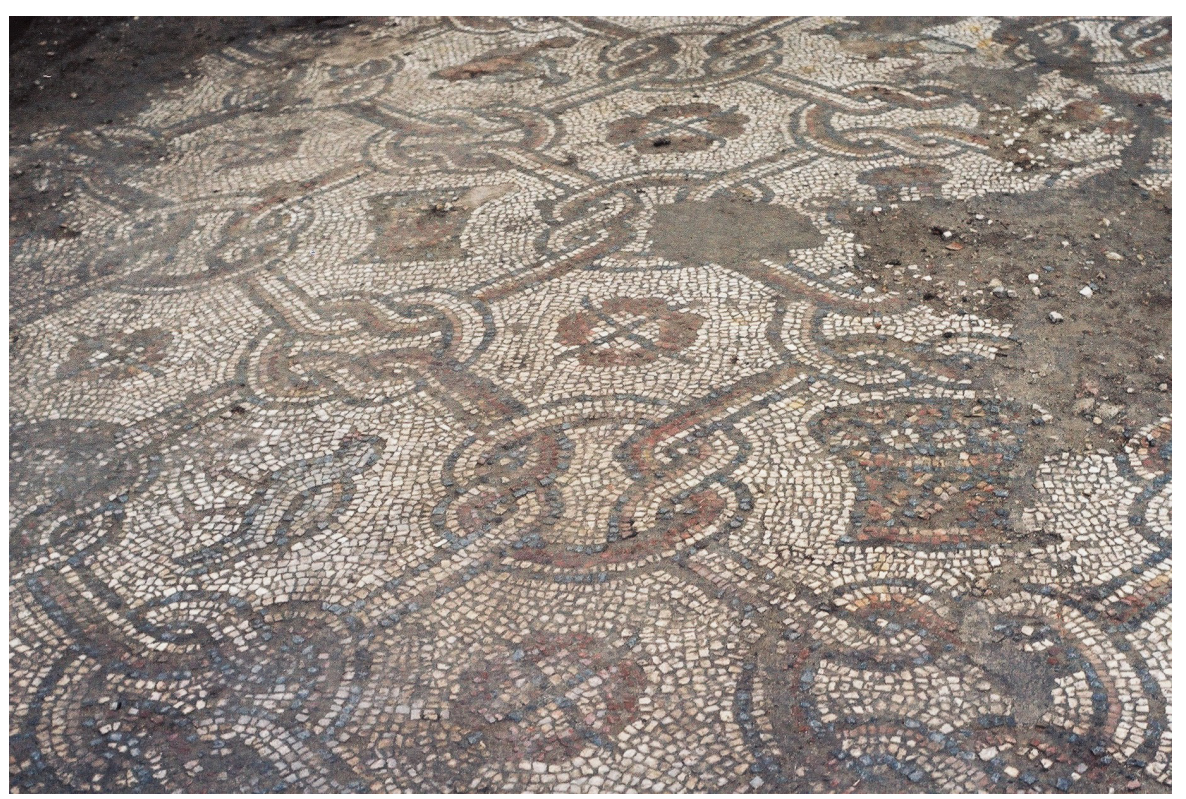

The same iconography filled the eastern panel in the northern aisle. The decoration in the western panel in the northern aisle is different. It is a variant of the polychrome orthogonal pattern of intersecting circles, which form saltires and concave squares with circles that are similar to those in the western panel of the nave (Décor I: pl. 238e - variant).

The mosaic floor in the narthex is more elaborate. It focuses on a central panel located in front of the main entrance. This panel holds the representation of a peacock with a spread tail facing eastward (Fig. 5) (Popova 2018: 158 pl. IV, 1).

Although the mosaic decoration of Philippopolis' episcopal basilica has not yet been entirely published, it has already been discussed with regard to several aspects such as its date (Kesjakova 2011: 193-194; Pillinger et al. 2016: 220; Popova 2018: 164-165; Topalilov 2020b: 259-262), the sequence of its respective panels' construction (Kantareva-Decheva 2018: 370-372), its importance for liturgical practices (Popova 2016: 163-166; 2018: 138-142; 147-150), defining mosaic ateliers (Kesjakova 2011: 194; Popova 2016: 164-165; Topalilov 2016a: 185-186), and problems of iconography and parallels (see most recently in Pillinger et al. 2016: 198-220; Popova 2016: 163-166; 2018: 138-140, 144-148). It is now assumed that the whole basilica received a new mosaic floor in the third quarter of the $5^{\text {th }}$ century and more specifically in the $50 \mathrm{~s}-60 \mathrm{~s}$ of the century. ${ }^{3}$ This new flooring covered the old mosaic pavement in all parts of the complex. It is also suggested that two different mosaic ateliers were involved in the mosaic pavements' construction. Thus, the first panel with figures in the naos is thought to be the work either of a metropolitan mosaic atelier or of a local Thracian atelier with strong Constantinopolitan influence (Popova 2016: 165). The mosaic
Figure 4

A detail from the western panel of the mosaic pavement in the south aisle of the Episcopal basilica in Philippopolis (Pillinger et al. 2016: taf. 156 Abb. 405).

3 Until the full publication of the results of the latest archaeological excavations the dates as well as the phases proposed in the literature - see Kantareva-Decheva 2018 remain unverifiable. 


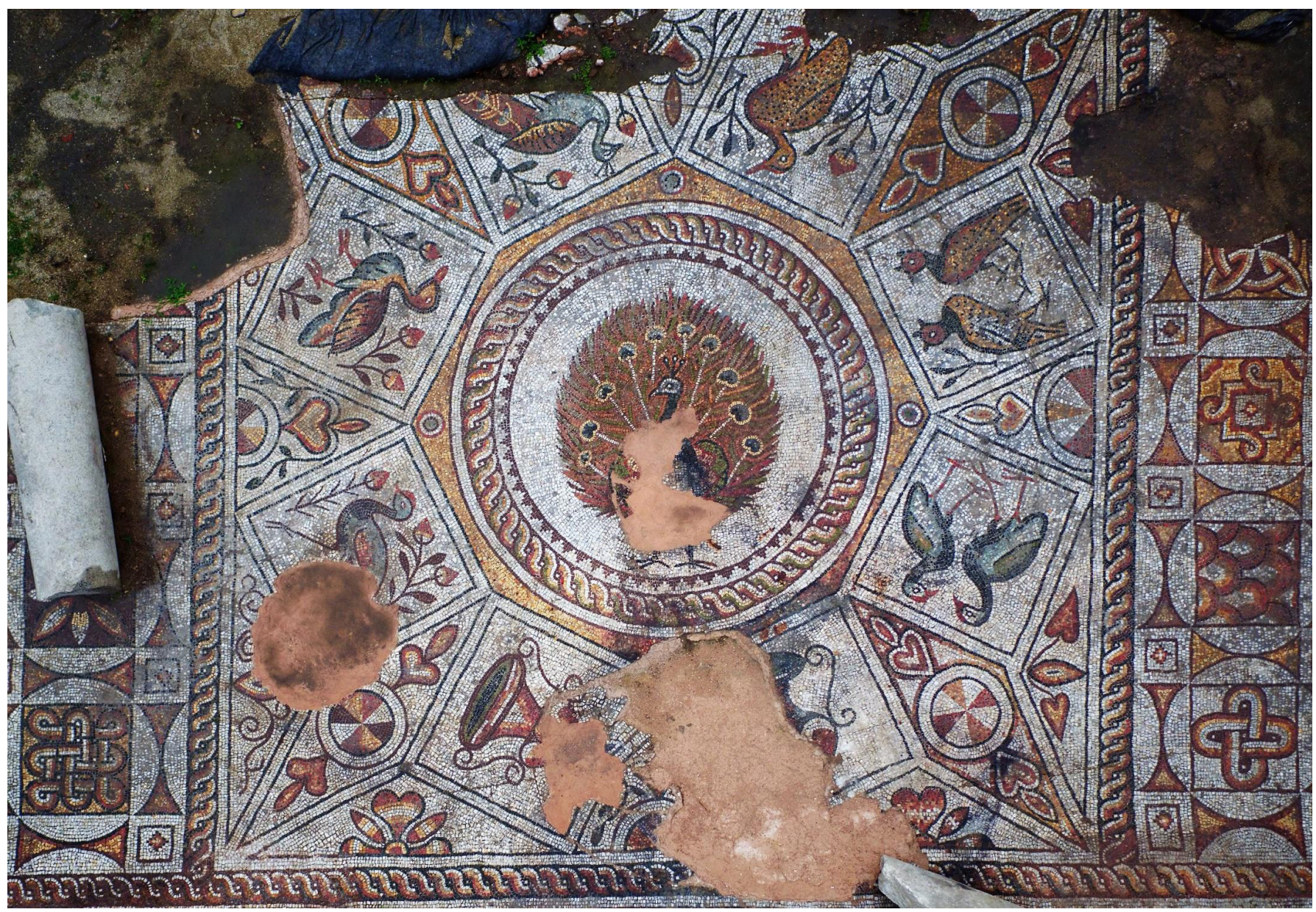

Figure 5

The image of the peacock in the atrium (after https://www.enjoy-plovdiv.com/en/ blog/great-basilica-of-philippopolis) (last consulted on March, 5, 2021). pavement in the north and south aisle are considered to be the work of another similar atelier. To these craftsmen should be also attributed the panel with the image of the peacock in the narthex (Popova 2016: 165 n. 41). It is noteworthy that both of these mosaic ateliers are still unattested archaeologically. It has been suggested, however, that all of the geometric panels in the northern aisle and central nave were made by local mosaicists (Topalilov 2021).

The replacement of the almost entirely preserved, earlier geometrical mosaic pavement raises the question of the reasons for this change. The large dimensions of the new mosaic program (more than $800 \mathrm{~m}$ sq.) suggests that it was a deliberate change that was intended to convey a new message rather than to simply repair the previous floor. This impression is also prompted by the fact that in another basilica that was built in Philippopolis around $475 \mathrm{CE}$, the so-called 'Small basilica,' geometric compositions not only prevail in the iconography of the basilica's mosaic floors but figural motifs are also entirely missing (Fig. 6) (Bospachieva 2002: 55-76; Pillinger et al. 2016: 227-239). Moreover, a major feature of the new program is the focus on the centers of the side aisles and of the narthex where the entrance is located. Specific images are placed at these key junctions in the mosaic decoration, such as the 'Fountain of life' and the full peacock, respectively, which present a sharp contrast to the rest of the mosaic decoration.

Indeed, these type of changes in mosaic decorative programs did not spread widely. For instance, they are not attested in the mosaics of the Christian basilicas in central and southern Greece, on the islands (see the corpora of Atzaka 1974; Asimakopoulou-Atzaka 1987), or along the West Asianic coast 


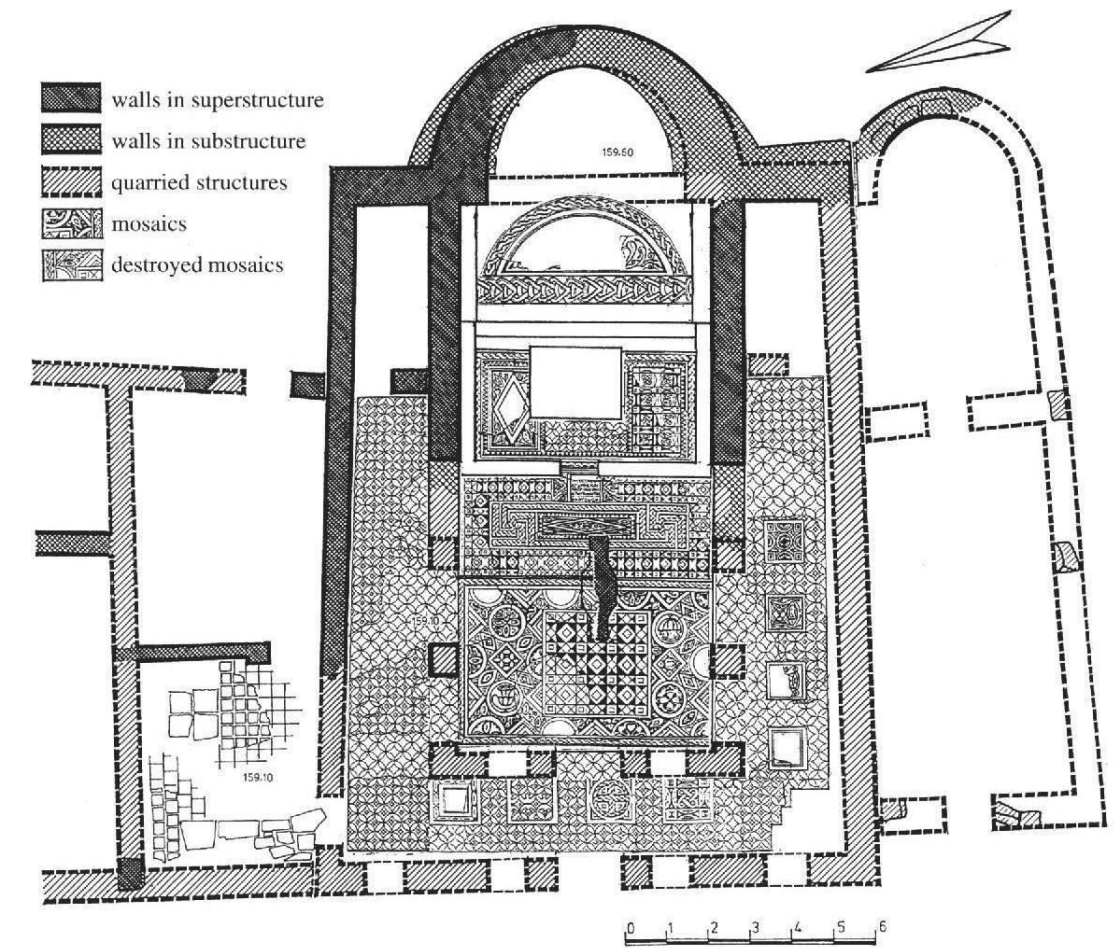

Figure 6

General layout of the mosaic pavements

of the so-called "Small basilica" in

Philippopolis (after Pillinger et al. 2016: Taf. 164 Abb. 422).

Figure 7

General layout of mosaic pavement of the "basilica Uvarov" at Chersonesus Taurica (after Dombrovskii 2004: 31).

\section{Figure 8}

General layout of mosaic pavement of the basilica No 14 at Chersonesus Taurica (after Biernacki et al. 2004: 46).
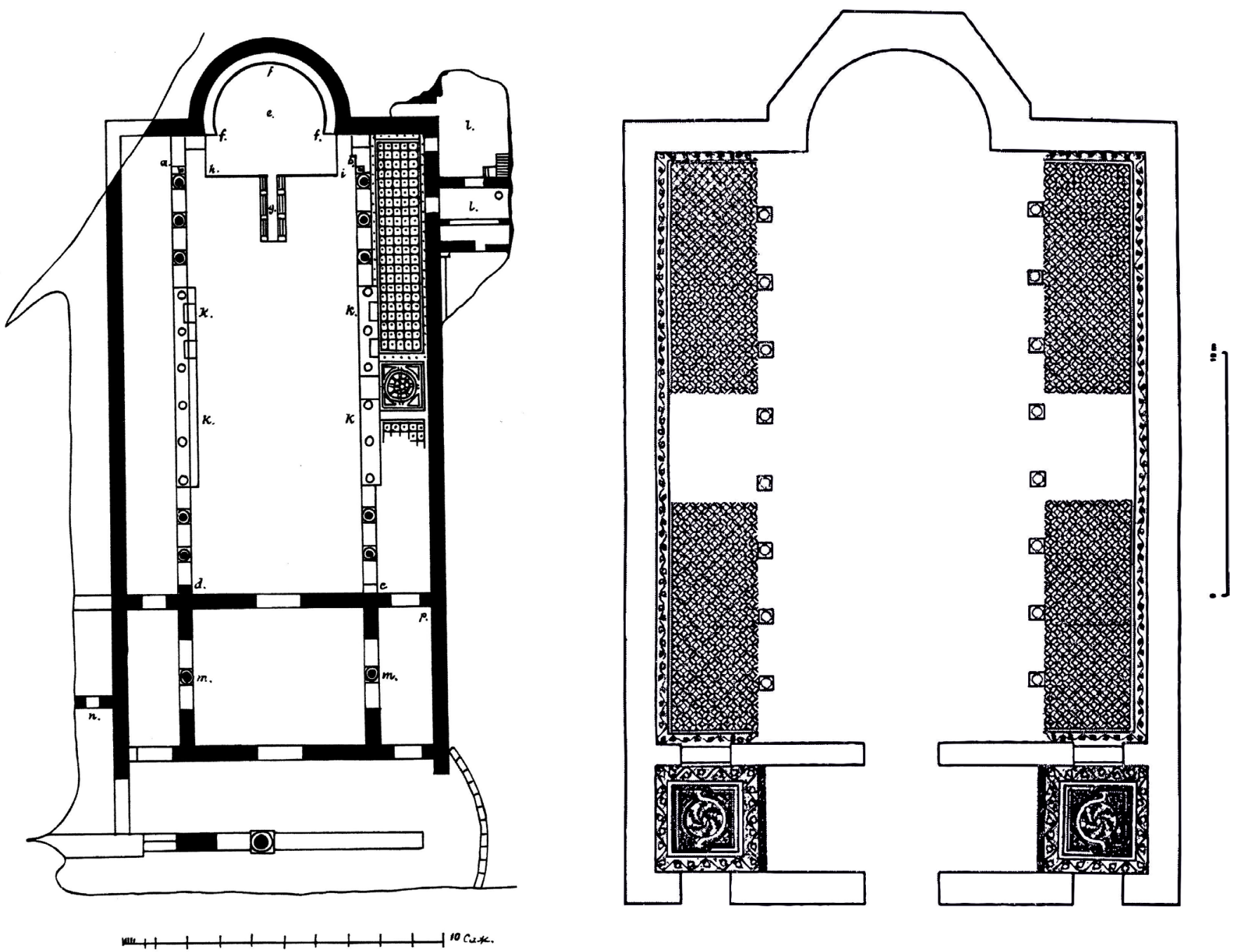
Figure 9

General layout of the cross-shaped memoria with mosaic floor at Chersonesus Taurica (after Dombrovskii 2004: 66 plan 10).
(Scheibelreiter-Gail 2011). They are, however, attested in some particular places such as the basilica at Heraklea (former Perinthos), the so-called basilica 'A' at Amphipolis dated in the second quarter of the $6^{\text {th }} \mathrm{c}$. (Asimakopoulou-Atzaka 2017: 362-364 pls. 333-337), and the basilicas at Chersonese Taurica in Crimea, which include the so-called 'basilica Uvarov' dated to the second half of the $5^{\text {th }}$ c. (Fig. 7) (Pülz 1998: 48-50; Biernacki et al. 2004: 74), the so-called 'basilica No 14' (Fig. 8) (Biernacki et al. 2004: 45), and the cross-shaped memoria dated to the second quarter of the $6^{\text {th }}$ century (Fig. 9) (Pülz 1998: 70-71; Biernacki et al. 2004: 94). Of particular interest for our study is the basilica at Herakleia since it is not only closer geographically to the basilica in Philippopolis - it is in the same diocese - but also chronologically. In fact, the similarities in the iconography of both basilicas' mosaic pavements has already been observed in the literature (Popova 2016: 165; Topalilov 2016a: 185-187; Westphalen 2016: 108-110). For the need of this study, a brief overview of the mosaic pavements of Herakleia's basilica is called for.

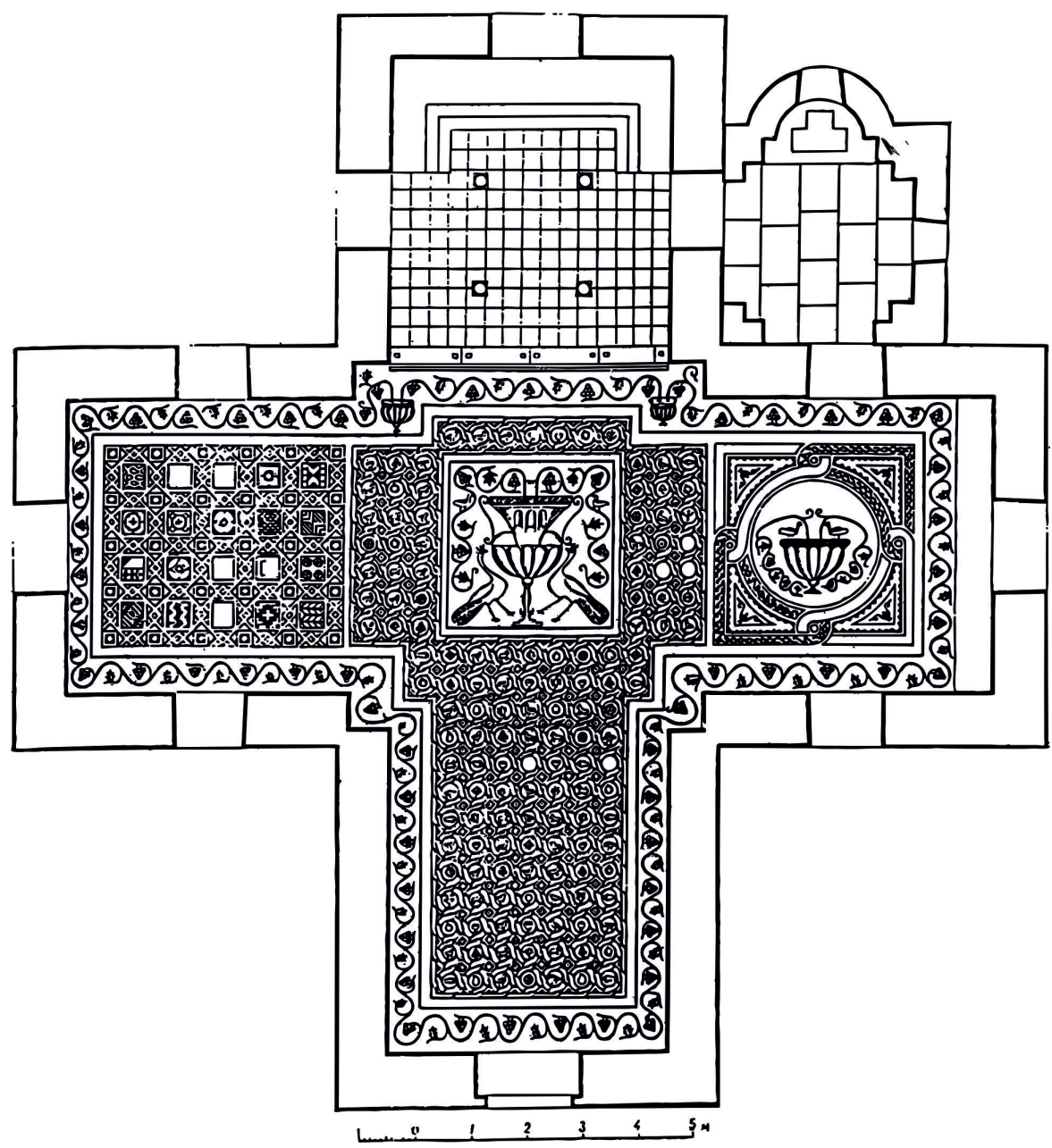

The mosaic of Herakleia's basilica, which St. Westphalen recently published in full (Fig. 10), was carried out in opus tessellatum and opus sectile, the latter of which was found in the atrium's chapel (Yeşil-Erdek 2014: 63, 69, 71-73; Westphalen 2016: 86). In the side aisles, the mosaics present a three-panel floor decoration with a central square as its focal point. The south aisle holds an image of a full peacock (Fig. 11) while the north one is filled with a fons vitae with two peacocks resting on both edges of a chalice (Fig. 12) (Westphalen 2016: Abb. 176-181). In comparison to the mosaic decoration of Philippopolis' 

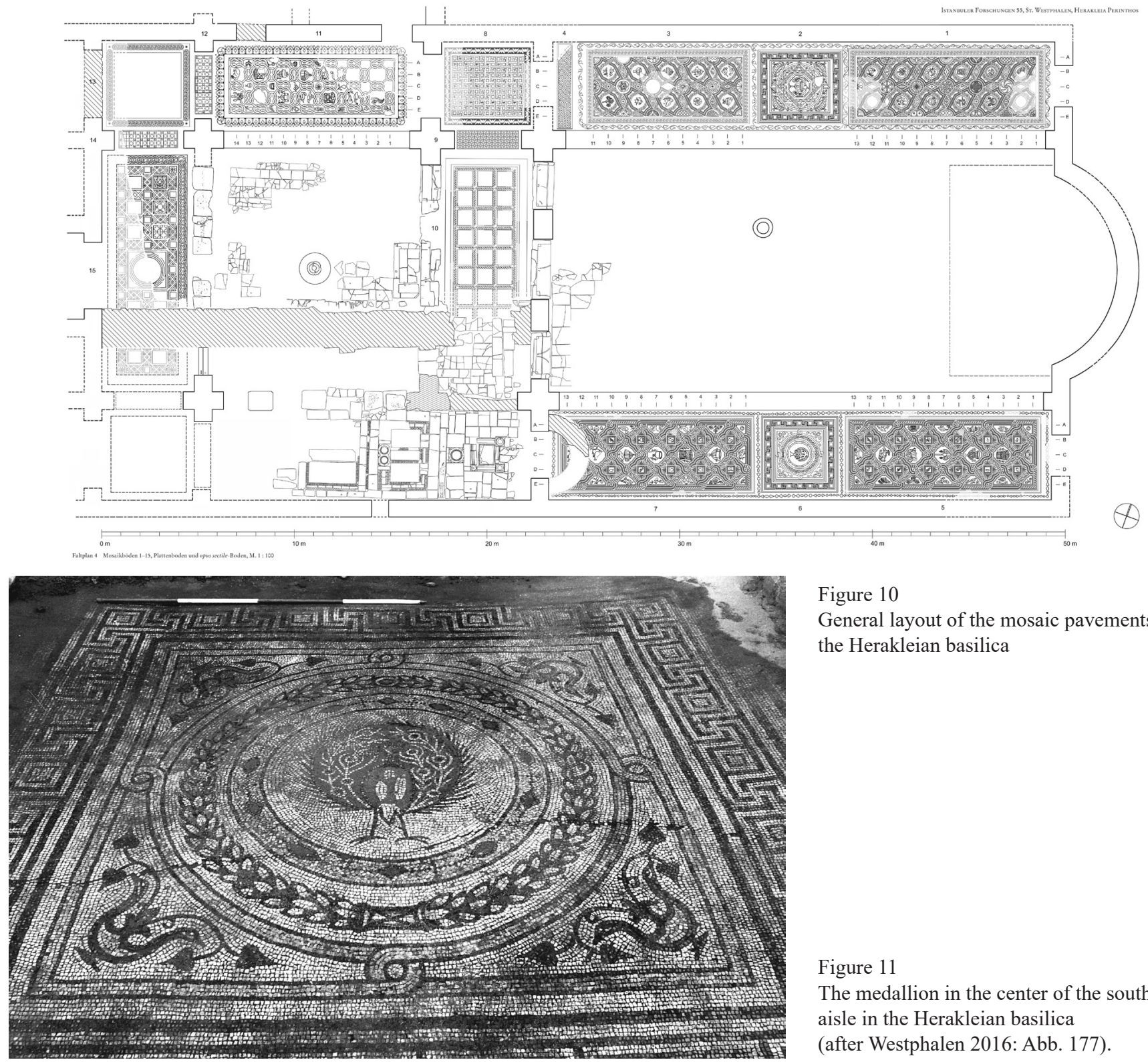

Figure 10

General layout of the mosaic pavements of the Herakleian basilica

Figure 11

The medallion in the center of the south aisle in the Herakleian basilica (after Westphalen 2016: Abb. 177).

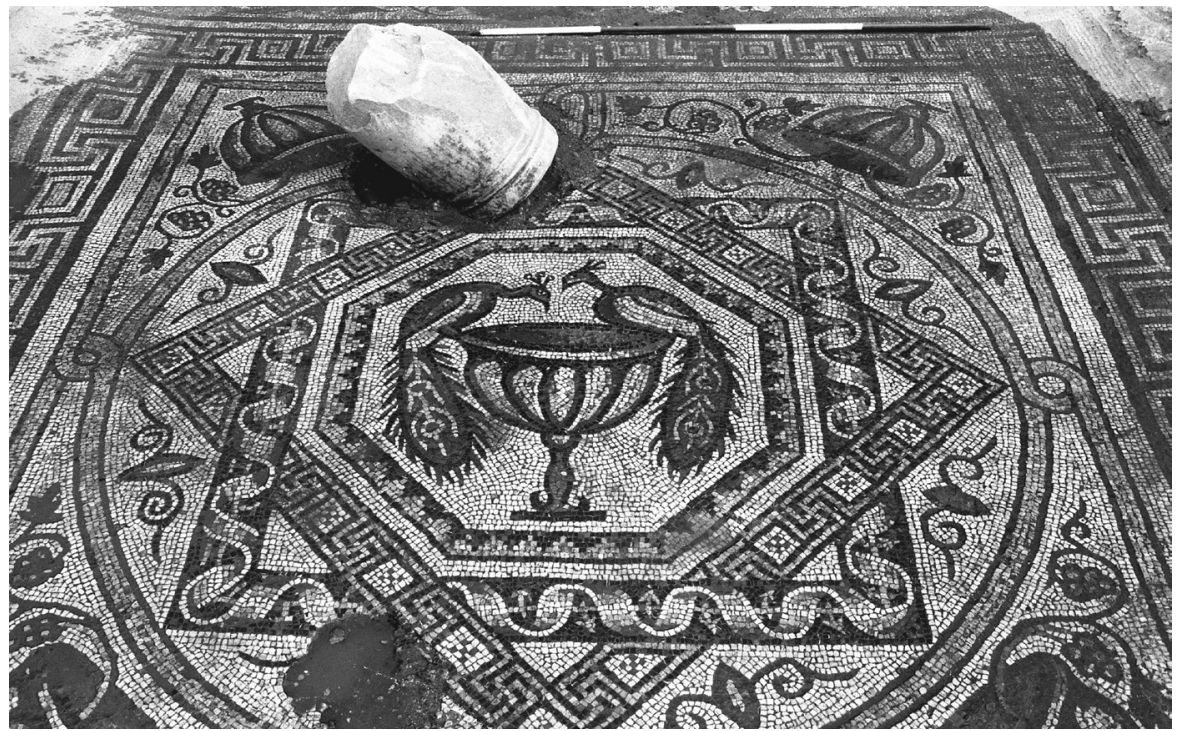

Figure 12

The medallion in the center of the north aisle in the Herakleian basilica (after Westphalen 2016: Abb. 176). 


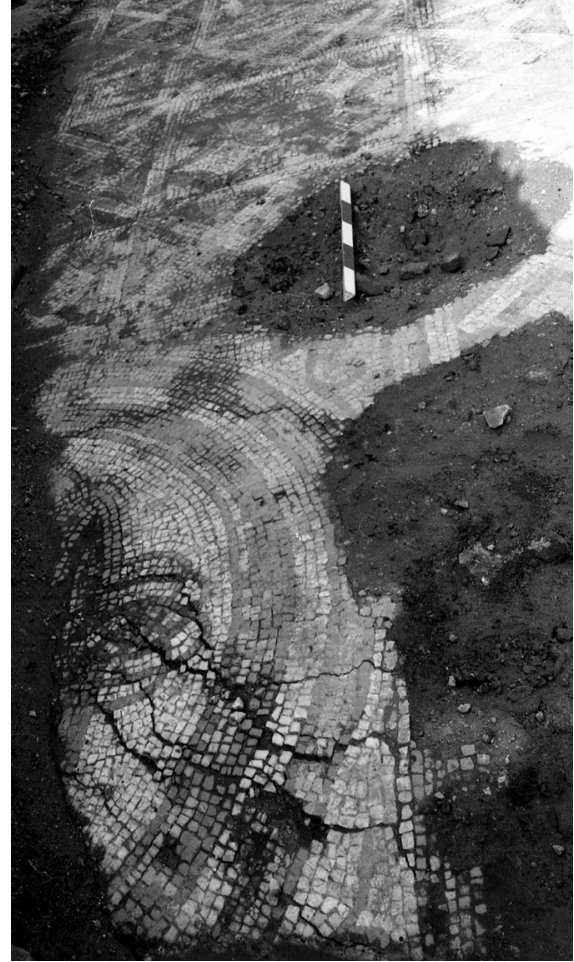

Figure 13

The "entrance" medallion image of the atrium of the Herakleian basilica (after Westphalen 2016: Abb. 236). basilica, there are some differences in the geometric schemes and some of the figures included in the mosaics of Herakleia's basilica. These mosaics' central panels are also somewhat different. For example, a peacock is set at the center of the southern aisle of Herakleia's basilica, and the 'fons vitae' motif appears dissimilar to that which appears in the mosaics of Philippopolis' basilica. Despite these differences, it is clear that the main idea remains the same: the mosaic decorations at both basilicas center on key scenes in the side aisles.

Another point of focus is the 'entrance' panel of the mosaic pavement in the atrium, which is oriented toward the atrium and decorated with a chalice with a small pouring stream (Fig. 13) (Yeşil-Erdek 2014: 71 fig. 7; Westphalen 2016: 197 Abb. 236). A discrepancy may also be observed between both examples under consideration in terms of the image of a full peacock, which is in the narthex in Philippopolis and the chalice which is in the atrium in Herakleia.

The construction of the Herakleian basilica is dated to 450-480 CE based on the significant similarities between this basilica and the monastery basilica of St. John in Studion (Westphalen 2016: 27-77). ${ }^{4}$ This date is supported by the archaeological material and specifics of the architectural decoration of Herakleia's basilica (Westphalen 2016: 15). Despite the lack of the typical polygonal outer wall of the apse, the measurements, plan, proportions, and architecture of Herakleia's basilica follow those of the basilica of St. John in Studion in Constantinople, which undoubtedly reveals that the construction of the Herakleian basilica was heavily influenced by Constantinople.

The atelier that made the mosaic pavement of Herakleia's basilica, however, is still under debate. Thus, St. Westphalen believes that the mosaic pavements in both Philippopolis' and Herakleia's basilicas were produced by a Thracian atelier (Westphalen 2016: 109 n. 149). V. Popova expresses a different opinion. As mentioned above, she believes that the mosaic in the side aisles was laid by a still archaeologically unattested metropolitan atelier ${ }^{5}$ or one strongly influenced by Constantinople. She further asserts that this craftsman produced some mosaics in Philippopolis - viz. the south aisle of the Episcopal basilica and on Puschkin Str. (Popova 2016: 165 n. 41). The mosaics of Philippopolis and Herakleia's basilicas, however, differ iconographically in some aspects and perhaps chronologically as well. For example, the Philippopolis mosaics are more nuanced in terms of shading, viz. the figural passages, with a greater range of geometric patterns. The Philippopolis and Herakleia peacocks are also differently conceived, with the former featuring straight feathers and the latter curved ones. It remains unclear to me which scenario is more likely: that an itinerant atelier influenced by Constantinople and based in Thrace executed the jobs or that they were carried out by ateliers based in the capital who travelled around to execute high-level projects. ${ }^{6}$ In either case, different completion dates for these projects would explain differences in style and execution. What is clear, however, is that in the second half of the $5^{\text {th }}$ century in some specific areas like both provincial capitals in the diocese of Thrace and Crimea, a new iconographic program was introduced in important Christian basilicas that later also spread

4 On the date of construction of the monastery in Studion - see Mango 1978: 115-122; Peschlow 1982: 429-334.

5 On the archaeological record of floor mosaics in Constantinople - see Dalgıç 2008; 2010: 127-134; 2011: 223-235; 2015: 15-48

6 Indeed, texts do not support the idea of floor mosaic ateliers based in the capital travelling around to execute high-level projects, but this possibility should not be excluded as we are aware of similar cases with the wall mosaic ateliers, such as the Umayyad wall mosaics of the Great Mosque of Damascus, though debated. 
other areas such as around Thessalonica. In this program, important locations in the basilica - the 'entrance area' in either the narthex or atrium and the centers of the side aisles - are highlighted through the introduction of specific images. Such images prominently include a kantharos or chalice with two peacocks resting on both edges, a peacock with a spread tail, and a single chalice, all of which are emphasized by their placement at the center of a special medallion and by their bigger size, polychromy, and lavishness. It seems, then, that the mosaic programs of both Philippopolis and Herakleia's basilicas belong to an intermediate period in the development of the iconography of the ecclesiastic floor mosaic. This decorative flooring was initially treated as a unit with a purely ornamental pattern but in the $6^{\text {th }} \mathrm{c}$. was commonly subdivided into a sequence of panels dominated by various enclosed animals, plants, fruits, and objects (Maguire 1987: 83; Raynaud 2009: 138-139 n. 24, 31). The mixed figural and geometric designs of the mosaic programs in Herakleia and Philippopolis's basilicas corroborate a date in this transitional span of time.

The interpretation of these motifs in both places have already been discussed in the literature. Thus, for the Herakleian motifs St. Westphalen suggested that the peacocks should be associated with the common symbolism of immortality and eternal life, and the chalice and wine in the northern medallion can be understood in the Eucharistic sense (Westphalen 2016: 109-110). ${ }^{7}$ On the other hand, the fons vitae in the southern aisle of Philippopolis' basilica is interpreted by V. Popova in connection with the new cult to Mary that emerged during the reign of Leo I (457-474) - that of Mary the Life-Giving Spring (or Life-giving Font). Popova believes that the dimensions of the vessel and its dominating presence is reminiscent of the basin with the Virgin blessing and embracing the Child that is found in Medieval and Revival period icons. As it was not appropriate at the time to depict the Mother of God on the floor, she assumes that the image of the kantharos itself symbolized this cult of Mary and that the entire aisle was devoted to Mary (Popova 2016: 164-166, 174). Given the nature of the cult, its introduction and spread in Thrace should undoubtedly be regarded as a direct influence from Constantinople (Popova 2018: 148). As for the image of the peacock in the narthex of the Episcopal basilica in Philippopolis (Fig. 5), this image is linked with the Eucharist, and the reverse orientation of the image is in accordance with the position of a bishop facing the laity that gathered in the atrium during the rite (Popova 2018: 140).

Certainly, the Christian reinterpretation of the motifs dominating the mosaic pavements in the side aisles, narthex and atrium in both basilicas is not a foregone conclusion. As is well evidenced, the use of various motifs (including those from the everyday life) in ecclesiastical floor decoration is not uncommon practice, and both mosaics under discussion provide good examples for this with the incorporation of local birds and other motifs in the geometric patterns. The fact that the scenes of the kantharos/chalice with two peacocks resting on both edges, of a peacock with a spread tail, and of a single chalice dominate the mosaic floor in particular areas of the basilica complex in the manner described above clearly points out to me that they have been placed due to their interpretatio christiana and belong to a new iconographic repertoire for ecclesiastic mosaic decoration. If we accept, however, the above-mentioned interpretation regarding the cult to Mary, the image of the cup (chalice) depicted at the center of the northern aisle of the Herakleian basilica is more suggestive of this cult rather than the image in the Philippopolitan mosaic with its two-stage structure. The depiction of the

7 The image of the kantharos turned into a fountain by the depiction of a small stream, which is enclosed in the medallion of the "entrance" mosaic to the atrium, remains undiscussed. 
kantharos-fountain may also resemble the Eucharistic chalice in a form that is attested elsewhere. ${ }^{8}$

Although the Christian interpretation of the motifs under consideration is debatable $^{9}$, it seems that the new iconographic program emphasizes the greater importance that the entrance and side aisles gained in the second half of the $5^{\text {th }}$ century in a way that became common in the next century. ${ }^{10}$ The deliberate use of figural ornamentation and scenes in special medallions in these areas is in sharp contrast to the geometric decoration floor that covered the rest of both basilicas.

These newly decorated parts, however, played important roles in some rituals that were vital to the Constantinopolitan liturgy, such as the processions revealed by the writings of its bishops Gregory of Nazianzus and John Chrysostom. Unsurprisingly, Christian basilicas at that time "consisted of a succession of expansive spaces opening into one another and lighted from all sides: atrium, aisles, galleries, and nave," and the liturgy itself was a "liturgy of processions" (Mathews 1982: 125). This is clearly visible in one of the most important ceremonies, that of the "First Entrance," in which initially all the faithful participated. The bishop received acclamation by the laity that gathered at the atrium, and after the clergy performed the rites of entry in the narthex, everyone simultaneously entered the naos lead by the bishop (Mathews 1971: 144-145; Taft 1992: 33-34). ${ }^{11}$ The laity entered the church through several doors, the socalled "Little Entrance," at the same time as the clerical procession led by the bishop, which allowed them to witness the procession itself (Mathews 1971: 138-145; Taft 1992: 33-34; 1998: 59-60). In the case with Philippopolis, we may assume that the bishop entered the naos trough the main entrance, while the rest of the clergy by the side doors of the main entrance. ${ }^{12}$ Similar is the 'Great Entrance' when bread and wine was carried in and the deacons also carried in holy elements with incense and candles, around which the faithful prostrated (on the ceremony and its development - see Mathews 1971: 155-176; Taft 1975; Mathews 1982: 125-126).

The processions, however, were not only confined only to the limits of the basilica. Herakleia and Philippopolis were without any doubt among these cities where the lithian and other type of processions were practiced, such as the stational liturgy led by the local bishop. The proximity of Constantinople where these processions were very popular (Baldovin 1987: 167-226), the direct influence of the Constantinopolitan bishop over that of Philippopolis (which is attested in the literary sources as is noted below), and the specific development of the political and religious process in Thrace, viz. the Gothic wars and Arianic past, were all crucial factors for the implementation of the Constantinopolitan liturgy in local religious life. Archaeology provides a clue for one of these processions in Philippopolis, which started from the imposing conch martyrium that was located some $70 \mathrm{~m}$ off the porta triumphalis and dedicated to the 38 martyrs of Philippopolis and Byzie. This procession continued through the gate and up the new main street of the city, which was 24 m wide and lavishly decoration on

8 See the examples and literature provided in Raynaud - Islami 2018: 234-236.

9 See for this Bisconti 2000; Bisconti - Gentili 2007.

10 See for example Kitzinger 1977; Cvetković-Tomašević 1978; Perseng 2021: 338-348.

11 This is also proved by the lack of numerous additional entrances in the north and south wall in both basilicas. Unlike the naos, however, this may be applied to the atrium of the Herakleian basilica. On the examples from Greece, see Caraher 2003: 100-101.

12 The three entrances of the naos in the Philippopolitan basilica are clearly distinguished in the mosaic floor - the central marked with the image of the peacock while the rest - by geometric panels. 
both sides with double-stored porticoes, and then finally reached the Episcopal basilica directly or via the domus episcopalis that is located just $30 \mathrm{~m}$ north of the basilica and linked by a special cardo, which was constructed regardless of the existing street-grid..$^{13}$ The procession reached the monumental propylaea of the Episcopal basilica's main entrance and ended in the atrium where some liturgical actions were pursued, as we can assume by the altar found there in situ (on the inscription on the altar - see Sharankov 2018: 731). ${ }^{14}$ The gathering of the laity at the atrium allowed the bishop to address them, and the image of the full peacock in the central medallion in the narthex mosaic may mark his place given the orientation of the figure itself.

Although there is no direct evidence yet for these processions at Herakleia, the mosaic floor decoration implies the involvement of the basilica in such liturgical activities. As was already mentioned, the Herakleian 'entrance' mosaic is decorated with a chalice with a small pouring stream and is oriented toward the atrium (Yeşil-Erdek 2014: 71 fig. 7; Westphalen 2016: 197 Abb. 236). This "sacro fonte" clearly marks the entrance of the basilica for processions of the faithful that began outside the basilica under the guidance of the bishop or another member of the clergy (Mathews 1971: 138-147). The symbol on the floor mosaic indicates the solemn entrance of the faithful and processions into the basilica. It is known that the ceremony itself was among the spectacular events that drew crowd's eager to see how the clergy entered the church (John of Ephesus HE, 3.3).

As was noted above, the Constantinopolitan liturgy was the "liturgy of processions.' The simultaneous entrance of the laity with the bishop in the 'First entrance' and the 'Little entrance,' the former in the side aisles and the latter in the central nave, allowed the people to witness the clerical procession and so reveals the importance that the side aisles of the basilica gained at that time. By this, the laity were undoubtedly included in the liturgy, especially given the fact that they also experienced the liturgy when they watched the clergy walk down the nave and around the altar (Caraher 2003: 106-110). Processions are now an important part of the liturgy itself. It is unclear, however, if this area was also a processional space as suggested in the literature in the case of the southern aisle of the Episcopal basilica in Philippopolis. ${ }^{15}$

Although fragmented, this evidence reveals a possible connection between the mosaic floor decoration and the liturgy. Both the mosaics and the liturgy emphasize particular parts of the basilica in the side aisles and narthex/atrium, the former by focusing attention on specific areas through the use of charged Christian symbols and the latter by including these areas into various rituals. This novelty is clearly attested when compared with the iconography of the older, entirely geometric mosaic pavement in the Philippopolitan basilica, which still found its place in the new iconography.

If all this is correct, we may go further and discuss the function of one of the rooms in the atrium of the basilicas at both Philippopolis and Herakleia. The so-called "room C" located in the southern portico at Philippopolis received

13 On the bishop's residence - see Dinchev 2002: 223 n. 15; Bospachieva 2003; Valeva 2011: 36-41; Pillinger et al. 2016: 174-198; Topalilov 2018; Popova 2021, on the Eastern Gate complex - see Martinova-Kjutova - Sharankov 2014; Topalilov 2016c; 2020a, on the road - see Martinova-Kjutova - Pirovska 2011; Topalilov 2016 b.

14 On monumental entrances and churches see Yasin 2017.

15 See for this V. Popova who assumes that the Fountain of Life mosaic implies glorification through a procession that stopped at this place and after that entered the naos from the south aisle (Popova 2016: 164). 
geometric decoration that held images of a kantharos and a basket with breads (Fig. 14), and the room in the northern portico of the Herakleian basilica had a mosaic that had depictions of a kantharos and basket among other figural motifs (Figs. 10, 15). The mosaic decoration of both places is in sharp contrast to that of the rest of the atrium, which was decorated entirely with geometric mosaics. The exact function of these ancillary rooms remains unclear, but this may have been the place where the wine and bread for the Eucharist was stored before it was carried into the naos. ${ }^{16}$

Figure 14

Fragment of the mosaic floor of room "C" in the atrium of the Episcopal basilica in Philippopolis (Archive: E. Kessjakova).

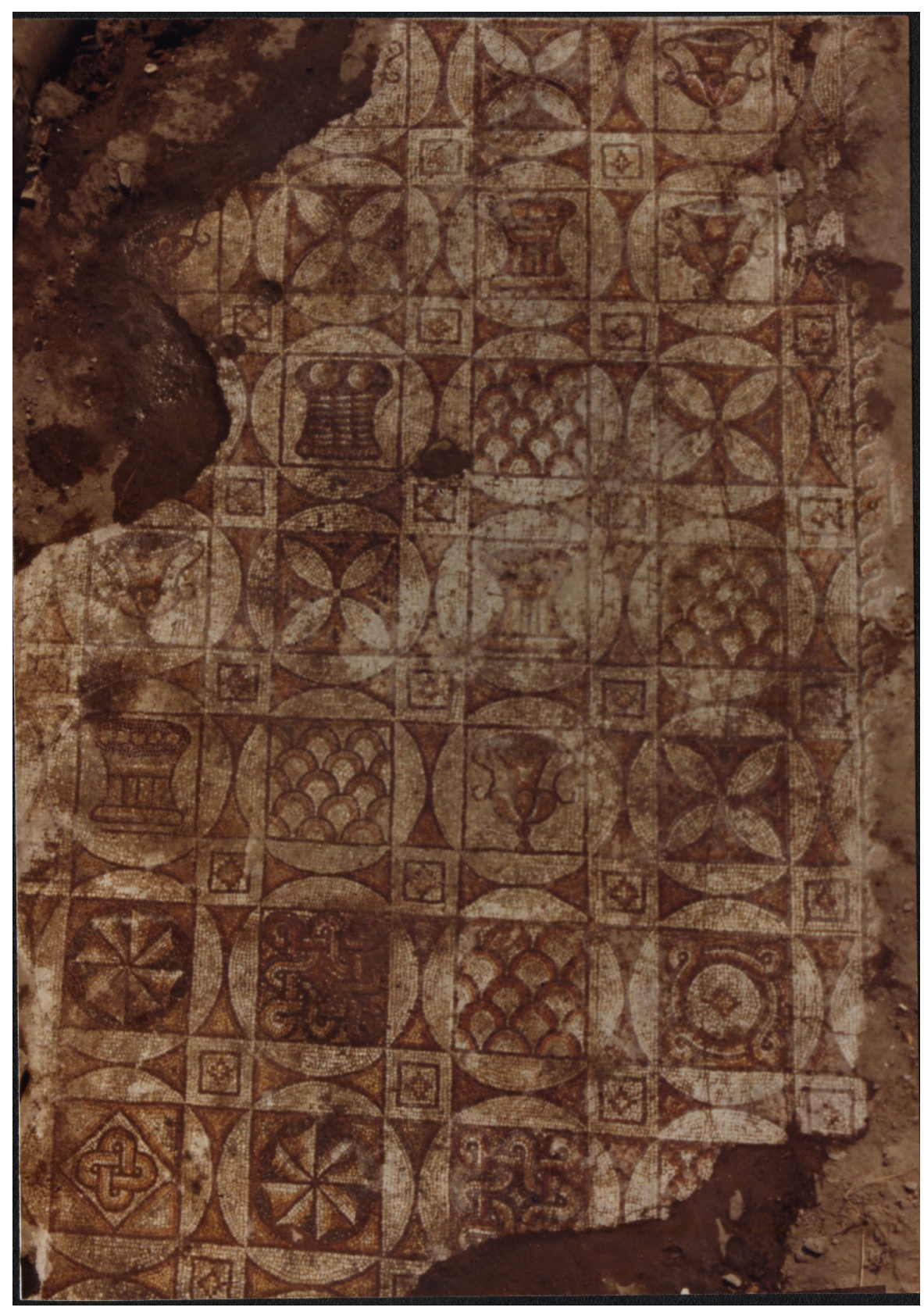

16 Indeed, the wine and bread were typically stored in a side room on the east side of the basilica, usually at the end of the aisles. However, no indication of such subdivision is attested at both basilicas, nor implied somehow, for example, by the floor decoration or the lack of it, as is well attested in other similar cases including in Philippopolis itself with the so-called 'Small basilica'. 


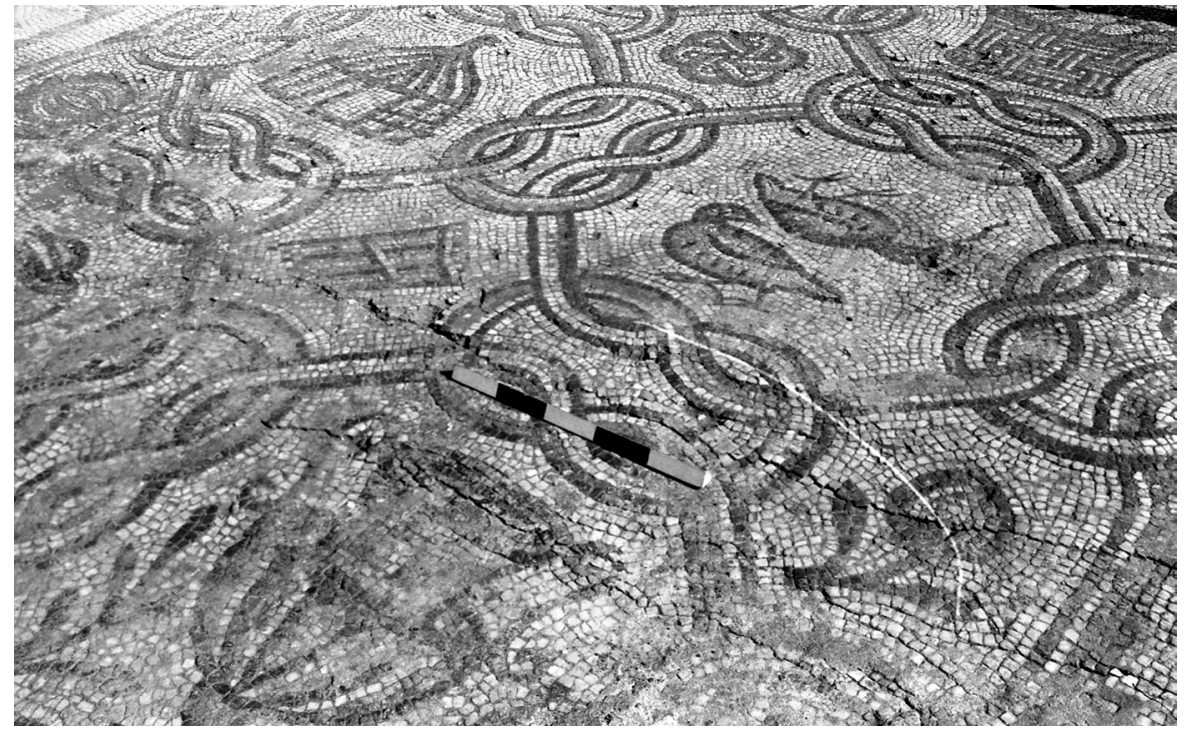

Indeed, this review of the changes that occurred in the mosaic decoration in two basilicas in two important provincial capitals in Thrace - Herakleia and Philippopolis - from the middle to third quarter of the $5^{\text {th }} \mathrm{c}$. is far from complete. Although the exact meanings of the symbols used in the basilicas' mosaics are debatable, it is clear that their use underlined the importance of the side aisles and the 'entrance' area. It is also clear that these parts of the basilicas gained new importance in the Constantinopolitan liturgy that was established in the late $4^{\text {th }}$ century. Given the close geographic proximity and the influence of the Constantinopolitan bishop in both centers, which in Philippopolis is attested in the literary sources, ${ }^{17}$ one wonders if these changes are not due to the spread of the metropolitan liturgy in the hinterland. It should be underlined that these are not the only novelties found in Thrace that have been heavily affected by innovations at Constantinople. ${ }^{18}$ The almost simultaneous appearance of these changes in the third quarter of $5^{\text {th }}$ century may imply that they were deliberately introduced and spread in Thrace and so were a part of a well-organized process rather than phenomena that were accidentally introduced. The structures in which these changes were found, in our case the Episcopal basilica in the Thracian capital Philippopolis and a basilica in Herakleia the capital of the province of Eurōpe, were among the most important in the provinces. In fact, the former basilica is probably the biggest in the diocese of Thrace while the latter is closely linked architecturally to Constantinople. The introduction of the new concept in the iconography of the mosaic pavement was made either by metropolitan ateliers or ateliers influenced by them; the former scenario seems preferable. It seems a full integration of Thrace into the metropolitan liturgy was sought, which could be regarded as a consequence of the expansion of the metropolitan jurisdiction officially after canon 28 at the Fourth Ecumenical council at Chalcedon in 451 CE. This canon states:

'so that, in the Pontic, the Asian, and the Thracian dioceses, the
Figure 15

The mosaic floor of the room in the northern room of the atrium in the Herakleian basilica (after Westphalen 2016: Abb. 231).

17 In this case it is about the request of the Philippopolitan bishop Sylvanus who asked the metropolitan bishop Aticus to be removed from Philippopolis to another place with a mild climate, which dates to the first half of the $5^{\text {th }}$ century - see for this Sokr. 7.36, 37 .

18 The introduction of the polygonal outer shape of the apse, for example, is one of best attested, and accordingly the semi-circular shape of already existing basilicas were remodeled to obtain the new form - see for these churches in Chaneva-Dechevska 1999. The example with the so-called "basilica no. $3^{\prime}$ ' is very significant in this aspect - for the basilica see Madzharov 1993: 130-132. Among the other novelties is the emergence of the small chapel attached to the narthex that also dates to this time - see the examples in Chaneva-Dechevska 1999: 102-104. 
metropolitans only and such bishops also of the Dioceses aforesaid as are among the barbarians, should be ordained by the aforesaid most holy throne of the most holy Church of Constantinople; every metropolitan of the aforesaid dioceses, together with the bishops of his province, ordaining his own provincial bishops, as has been declared by the divine canons; but that, as has been above said, the metropolitans of the aforesaid Dioceses should be ordained by the archbishop of Constantinople, after the proper elections have been held according to custom and have been reported to him'. 19

By this decision, the council confirmed de jure an already existing situation with the appointment of the highest church clergy in the area by Constantinople's bishop. The aforementioned case with the Philippopolitan bishop Sylvanus is a good example of this. The already established close link between Thracian Christian communities and Constantinople may date back to the time of Theodosius I when firm control over the provinces in Thrace was required due to their "Arianic" past and the so-called "Gothic Wars." It seems that if it was not the emperor himself, it was the bishop in Constantinople, whom he installed, who was involved in the process of appointing local Thracian bishops loyal to the emperor and to the Nicene creed and who therefore controlled church matters and communities in Thrace. The result of this development can be observed in the support that the Christians in Thrace provided to the metropolitan bishop Nestorius (428-431) and his doctrine, which may also be due to the "Arianic" past of these lands.

With canon 28, this Constantinopolitan domination was embodied also in the local liturgy, which was subject to some change because of the simple reason that new clergy came from Constantinople with different liturgical rites. On top of the fact that Thrace was under the official jurisdiction of Constantinople's bishop, all the events and changes echoed in Thrace, including the establishment of new cults, rites, and evolution of the liturgy and architecture, concerned new liturgical demands. In fact, we may assume that from the second half of the $5^{\text {th }}$ c. onward, the provincial structures may provide a good deal of information of metropolitan prototypes that are not preserved or have not yet been discovered.

The evidence available, although scanty, promotes questions concerning the material manifestation of the mechanism of integration in the traditions of certain provinces and respective churches and their liturgical life and concerning the direct and indirect metropolitan influences on art in the hinterland. In our case the importance of the latter question is exemplified by the introduction of new iconography in mosaic flooring that was executed either by a metropolitan mosaic atelier or by ateliers under the influence of Constantinople. Above all, though, it is clear enough that mosaic floor decoration started to play a significant active role in the liturgy of the Christian basilicas in certain regions. Indeed, some skepticism is expressed in the literature about the possible link between the images and liturgy, as is the case with the chalice and kantharos decorating the aisles of the Herakleian basilica (Westphalen 2016: 109-110). There is also the unclear case of the chalice and wine scene in the northern medallion of this basilica (Westphalen 2016: 109-110). The possible correlation between the particular

19 Canon 28: Ut et Ponticae, et Asianae, et Thraciae dioeceseos metropolitani soli: praeterea et qui sunt in barbarico, episcopi praedictarum dioeceseon ordinentur a praedicto sanctissimo throno sanctissimae Constantinopolitanae Ecclesiae. Nimirum unoquoque metropolita earum ipsarum dioeceseon, una cum episcopis provinciae ordinante provinciae episcopos, ut divinis canonibus promulgatum est. Metropolitas vero earum dioeceseon, sicut dictum est, ordinari a Constantinopolitano archiepiscopo, electionibus convenientibus secundum morem factis, et ad eum perlatis (Schwartz 1936). 
areas that received more remarkable floor decoration and those that gained more importance in the Constantinopolitan liturgy since the last quarter of $4^{\text {th }}$ century is a crucial for understanding the proposed link between the decoration and liturgy. Examples dating to the third quarter of the $5^{\text {th }}$ century, such as those in Herakleia and Philippopolis' episcopal basilicas, are among the first such cases when these innovations were not yet conceptualized. It was done as late as 475 $\mathrm{CE}$ as the iconography of the so-called 'Small basilica' in Philippopolis reveals, for which also a metropolitan influence is also suggested in the literature. The examples under consideration here thus present an intermediate period in this development that would find its complete form in the next century. Thrace and Chersonesos Taurica provide examples for these new changes that were inspired by Constantinople, given also the direct influence of the metropolis in the northern region. I have no doubt that examples of these changes can also be found in other regions in the empire, especially these included in canon 28 of the Fourth Ecumenical council. One should here call to mind the so-called 'Constantinopolitan' type of churches that spread in Syria at that time and later (see for example the study of Mulholland 2014). One should also look to other regions that were linked closely with Constantinople at that time, such as the area of Thessalonica and its hinterland. In this area, changes in mosaic floor decoration like those discussed here may be observed in monuments from the $6^{\text {th }}$ century. I admit that the scanty evidence now available is not yet compelling, but I do hope, however, that this study will help address questions concerning the links between the Constantinopolitan liturgy and episcopal architecture and floor and wall decoration in Thrace.

\section{Bibliography - Kaynaklar}

Asimakopoulou-Atzaka 1987 P. Asimakopoulou-Atzaka, Syntagma ton palaiohristianikon psefidoton dapedon tes Ellados, II. Peloponnesos - Sterea Ellada, Byzantina mnhmeia 7, Kentron Byzantinon Eregnon, Thessaloniki.

Asimakopoulou-Atzaka 2017 P. Asimakopoulou-Atzaka, Syntagma ton palaiohristianikon psefidoton dapedon tes Ellados, III. MakedoniaThrake. 2. Ta Psifidota Dapeda tes Makedonias kai tes Thrakes (ektos Thessalonikes), Byzantina mnhmeia 18, Thessaloniki.

Atzaka 1974

P. Atzaka, Syntagma ton palaiohristianikon psifidoton dapedon tes Ellados, I. Nesiotike Ellas, Byzantina mnhmeia 1, Kentron Byzantinon Eregnon, Thessaloniki.

Baldovin 1987

J. F. Baldovin, The Urban Character of Christian worship. The Origins, Development, and Meaning of Stational Liturgy, Orientalia Christiana Analecta 228, Roma.

Biernacki et al. 2004

A. Biernacki - E. Klenina - St. Ryizhova, Rannevizantiiskie sakral'nye postroiki Hersonesa Tavricheskogo, Poznań.

Bisconti 2000

F. Bisconti, Temi di iconografia paleocristiana, Città del Vaticano.

Bisconti - Gentili 2007

F. Bisconti - G. Gentili (eds.), La rivoluzione dell'immagine. Arte paleocristiana tra Roma e Bisanzio, Milano.

Bospachieva 2002

Bospachieva 2003

M. Bospachieva, “A small early Christian basilica with mosaics at Philippopolis”, ABulg 6/2, 55-76.

M. Bospachieva, "The Late Antiquity Building EIRHNH with Mosaics from Philippopoilis (Plovdiv, Southern Bulgaria)", ABulg 2, 83-105.

Caraher 2003

W. Caraher, Church, Society and the Sacred in Early Christian Greece. Dissertation submitted to the Ohio State University, Ohio.

Chaneva-Dechevska 1999

N. Chaneva-Dechevska, Rannohristijanskata architectura v Balgaria IV-VI v., Sofia.

Cvetković-Tomašević 1978

G. Cvetković-Tomašević, Ranovizantijski podni mozaici. Dardanija, Makedonija, Novi Epir, Filozofski Fakultet u Beogradu, Institut za Istoriju Umetnosti, Belgrade.

Dalgıç 2008

Ö. Dalgı̨̧, Late Antique Floor Mosaics of Constantinople prior to the Great Palace, Unpublished PhD Thesis, New York University, New York. 
Dalgıç 2010

Dalgı̧̣ 2011

Dalgıç 2015

Décor I

Dinchev 2002

Dombrovskii 2004

Kantareva-Decheva 2017

Kantareva-Decheva 2018

Kesjakova 2011

Kitzinger 1977

Madzharov 1993

Maguire 1987

Mango 1978
Ö. Dalgıç, "The Corpus of Floor Mosaics of Constantinople”, F. Daim - J. Drauschke (Hrsg.) Byzanz - das Römerreich im Mittelalter, Monographien des Römisch-Germanisches Zentralmuseum, vol. 84,3, Mainz, 127134.

Ö. Dalgıç, “Early Floor Mosaics in Istanbul”, G. Sözen (ed.) Mosaics of Anatolia, Istanbul, 223-235.

Ö. Dalgıç, “The Triumph of Dionysos in Constantinople: A Late Fifth-Century Mosaic in Context”, DOP 69, 15-48.

C. Balmelle - M. Blanchard Lemée - J. Christophe - J.-P. Darmon - A.-M. Guimier Sorbets - H. Lavagne - R. Prudhomme - H. Stern, Le Décor géométrique de la mosaïque romaine I, Paris, 1985.

V. Dinchev, "Kam harakteristikata na predstavitelnata kasnoantichna zhilishtna arhitektura v Thracia i Dacia”, Godishnik na Arheologicheskija Institut s muzei 2, 206-241.

O. Dombrovskii, Vizantiiskie mozaiki Hersonesa Tavricheskogo, Poznań.

E. Kantareva-Decheva, "Konservatsija i restavratsija na podovi mozaiki ot obekt "Episkopska bazilika na Filipopol” - Plovdiv 2015-2016 g.”, T. Shekerdzhieva-Novak (ed.), Proletni nauchni chetenija 2017, Plovdiv, 220-227.

E. Kantareva-Decheva, "Novi stratigrafski prouchvanija na mozaikata ot Episkopskata bazilika na Filipopol", T. Shekerdzhieva-Novak (ed.), Sbornik dokladi ot Mezhdunarodna nauchna konferentsiya "Nauka, obrazovanie i inovatsii v oblastta na izkustvoto", Plovdiv, 365-372.

E. Kesjakova, "Mozaiki ot episkopskata bazilika na Filipopol”, St. Stanev - V. Grigorov - V. Dimitrov (eds.), Studies in honour of Stefan Boyadzhiev, Sofia, 173-210.

E. Kitzinger, Byzantine Art in the Making: Main Lines of Stylisitc Development in Mediterranean Art, $3^{\text {rd }} 7^{\text {th }}$ century, Cambrigde, Mass.

K. Madzharov, Diokletsianopol, tom 1. Topografija, gradoustroistvo i arhitektura, Sofia.

H. Maguire, Earth and Ocean. The Terrestrial World in the Early Byzantine Art, London.

C. Mango, "The Date of the Studius Basilica at Istanbul", Byzantine and Modern Greek Studies 4, Essays Presented to Sir Steven Runciman, 115-122.

Martinova-Kjutova - Pirovska 2011

M. Martinova-Kjutova - G. Pirovska, "Iztochnata porta na Filipopol", St. Stanev - V. Grigorov - V. Dimitrov (eds.), Studies in honour of Stefan Boyadzhiev, Sofia, 211-233.

Martinova-Kjutova - Sharankov 2014

M. Martinova-Kjutova - N. Sharankov, "Novi danni za kompleksa "Iztochna porta na Filipopol", Annual of the Regional Archaeological museum - Plovdiv, 12, Proceedings dedicated to the $130^{\text {th }}$ anniversary of the Regional Archaeological Museum - Plovdiv (1882 -2012), 159-184.

Mathews 1971

T. F. Mathews, The Early churches of Constantinople: Architecture and Liturgy, Penn.

Mathews 1982

T. F. Mathews, “Private' Liturgy in Byzantine Architecture: Toward a Reappraisal”, CArch 30, 125-138.

Mulholland 2014

B. Mulholland, The Early Byzantine Christian Church. An Archaeological Re-assessment of Forty-Seven Early Byzantine Basilical Church Excavations Primarily in Israel and Jordan, and their Historical and Liturgical Context, Byzantine and Neohellenic Studies 9, Bern.

Perseng 2021

M. Perseng, "The iconographic and stylistic development of the Eucharistic images in the floor mosaics on the Balkans during the Early Christianity", M. Rakocija (ed.), Niš and Byzantium Symposium 16, Niš, 325-328.

Peschlow 1982

U. Peschlow, "Die Johanneskirche des Studios in Istanbul”, JbÖByz 32.4, 429-434.

Pillinger et al. 2016

R. Pillinger - A. Lirsch - V. Popova (Hrsg.), Corpus der spätantiken und frühchristlichen Mosaiken Bulgariens, Wien, 2016.

Popova 2016

V. Popova, "Fons Vitae in Late Antique monuments in Bulgaria", Studia academica Šumenensia 3, 154-198.

Popova 2018

Popova 2021

V. Popova, "Liturgy and Mosaics: The Case Study of the Late Antique Monuments from Bulgaria", M. Rakocija (ed.), Niš and Byzantium Symposium 16, Niš, 135-160.

V. Popova, "The personification of Eirene from the episcopal residence in Philippopolis/Plovdiv", M. Rakocija (ed.), Niš and Byzantium Symposium 16, Niš, 299-324.

Pülz 1998

A. Pülz, "Die frühchristlichen Kirchen des taurischen Chersonesos/Krim”, MitChrA 4, 45-78.

Raynaud 2009

M.-P Raynaud, Corpus of the Mosaics of Turkey, Volume 1: Lycia. Xanthos Part 1: The East Basilica, Bursa. 
Raynaud - Islami 2018

Scheibelreiter-Gail 2011

Schwartz 1936

Sharankov 2018

Taft 1975

Taft 1992

Taft 1998

Tankova 2017

Topalilov 2016a

Topalilov 2016b

Topalilov 2016c

Topalilov 2018

Topalilov 2020a

Topalilov 2020b

Topalilov 2021

Westphalen 2016

Valeva 2011

Yasin 2017

Yeşil-Erdek 2014
M.-P. Raynaud - A. Islami, Corpus of the Mosaics of Albania, volume 1. Butrint intramuros, Balkans' Mosaic 1 , Bordeaux.

V. Scheibelreiter-Gail, Die Mosaiken Westkleinasiens. Tessellate des 2. Jahrhunderts v. Chr. bis Anfang des 7. Jahrhunderts n. Chr., Österreichisches Archäologisches Institut, Sonderschriften Band 46, Wien.

E. Schwartz, Acta Conciliorum Oecumenicorum 2, 1, 2, Concilium Chalcedonense, Berlin - Leipzig.

N. Sharankov, "Epigrafski otrkitija“, Arheologicheski otrkritija i razkopki prez 2017, 731-734.

R. F. Taft, The Great, Entrance, A History of the Transfer of Gifts and other Preanahoral Rites of the Liturgy of St. John Chrvsostom, Orientalia Christiana Analecta 200, Rome.

R. F. Taft, The Byzantine Rite: A Short History, Collegeville.

R. F. Taft, "Quaestiones disputatae: The Skeuophylakion of Hagia Sophia and the Entrances of the Liturgy Revisited", OrChr 82, 53-87.

Zh. Tankova, "Arheologichesko prouchvane na obekt "Episkopska basilica", gr. Plovdiv, Arheologicheski otrkritija i razkopki prez 2016, 323-325.

I. Topalilov, “Local Mosaic Workshops in Late Antique Philippopolis, Thrace: Some consideration”, L. Neira Jiménes (ed.), Estudios sobre mosaicos antiquos y medievales, Roma, 183-188.

I. Topalilov, "The impact of the religious policy of Theodosius the Great on the urbanization of Philippopolis, Thrace (Preliminary notes)", O. Brandt - V. Fiocchi Nicolai (eds.), Costantino e i Costantinidi: l'innovazione costantiniana, le sue radici e i suoi sviluppi, Acta XVI Congressus Internationalis Archaeologiae Christianae, Roma, 1853-1862.

I. Topalilov, "The importance of the so-called 'Eastern Gate' complex for the Christians and Christianity in LA Philippopolis", M. Rakocija (ed.), Cities and Citizens in Byzantine World, Niš and Byzantium 14, (Niš: NKC), 265-274.

I. Topalilov, "On the Eirene mosaic from Philippopolis, Thrace”, JMR 11, 273-285.

I. Topalilov, "Porta triumphalis v kasnoantichna Trakija", N. Kanev (ed.), Vladetel, darzhava i tsarkva na Balkjanite prez Srednovekovieto. Sbornik v chest na 60-godishninata na Prof. d-r Plamen Pavlov, tom 1, Veliko Turnovo, 304-324.

I. Topalilov, "The Mosaic pavements in Philippopolis, Thrace, in $6^{\text {th }}$ c. CE. Some considerations", JMR 13, 257-279.

I. Topalilov, "The Early Christian basilicas in Philippopolis and Herakleia - two pieces of work of an unknown metropolitan mosaic workshop", (in press).

St. Westphalen, Die Basilica am Kalekapi in Herakleia/ Perinthos. Bericht über die Ausgrabungen von 19922010 in Marmara Ereğlisi, IstForsch 55.

J. Valeva, "Elitna zhilishtna architectura i dekor v dioceza Trakija (IV-VII v)", St. Stanev - V. Grigorov - V. Dimitrov (eds.), Studies in honour of Stefan Boyadzhiev, Sofia, 17-56.

A. Yasin, "The Pilgrim and the Arch: Channeling Movement and Transforming Experience at Late Antique Holy Sites", T. M. Kristensen - W. Friese (eds.), Excavating Pilgrimage: Archaeological Approaches to Sacred Travel and Movement in the Ancient Mediterranean and Near East, London, 166-186.

S. Yeşil-Erdek, "Perinthos-Herakleia Bazilikası Taban Döşemelerinin Konservasyonu”, JMR 7, 61-75. 